\title{
Bad Debt and Cost Efficiency in Vietnamese Commercial Banks
}

\author{
NGUYEN THI HONG VINH \\ Banking University HCMC - hongvinhnguyenvn@gmail.com
}

\section{ARTICLE INFO ABSTRACT}

Article history:

Received:

July 312014

Received in revised form

Oct. 292014

Accepted:

Dec. 302014
The paper aims at exploring the relationship between bad debt and cost efficiency in Vietnamese commercial banks in the years 2007 2013. The research includes two stages: (i) Measuring the cost efficiency of banks by non-parameter Data Envelopment Analysis (DEA) method suggested by Coelli (2005); and (ii) Applying the Tobit model to identify two-way effects of bad debt and bank cost efficiency. The results show that the cost efficiency in Vietnamese commercial banks is $52.6 \%$ and there exists a direct relationship between bad debt and cost efficiency.

Keywords:

Bad debt, cost efficiency,

Tobit, Vietnamese

commercial banks 


\section{Introduction}

Vietnam's economic reform and growth have stagnated due to the accumulation of bad debt in the banks. According to the SBV, the proportion of bad debt in the period 2007-2013 has increased compared with the previous years (Fig. 1).

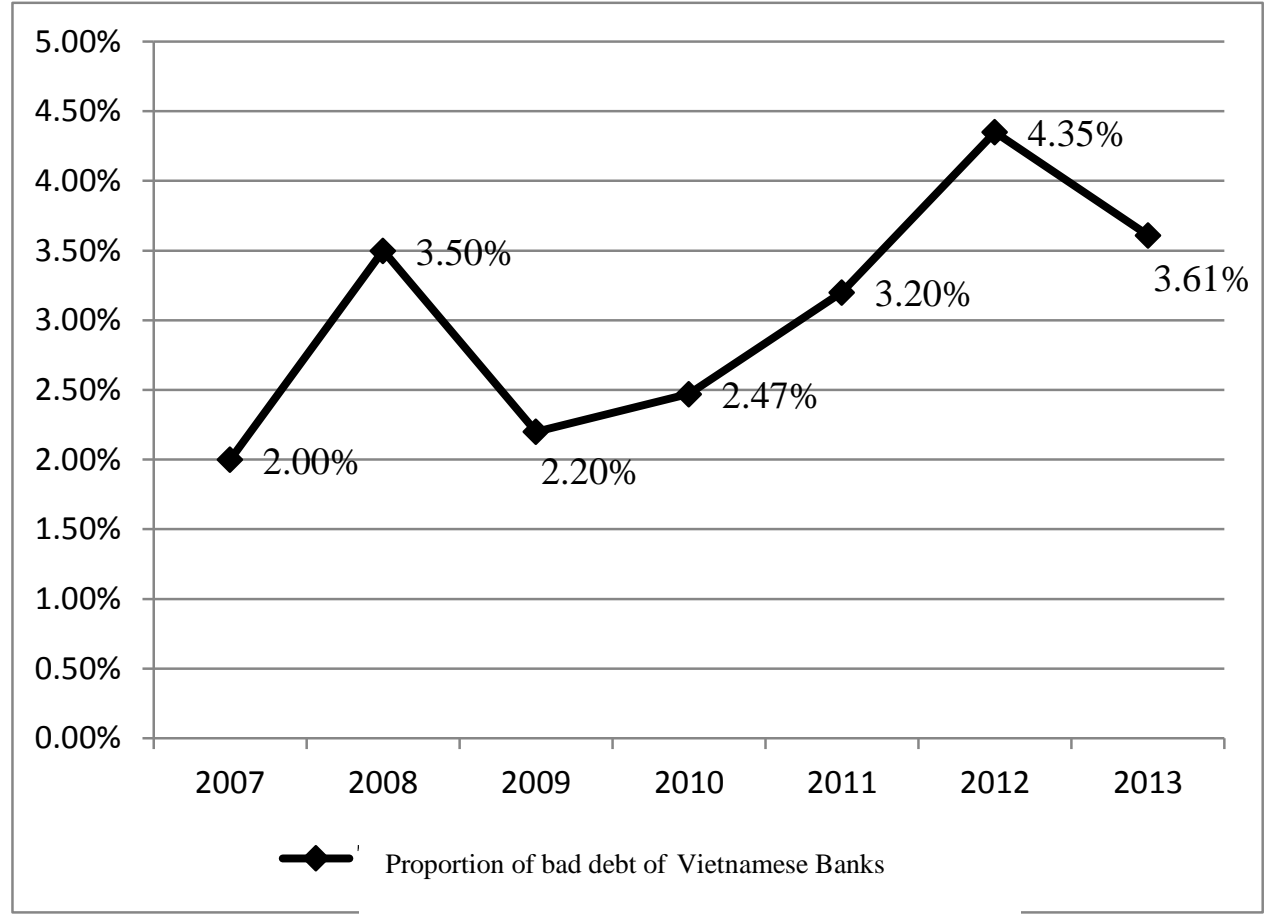

Fig. 1. Proportion of bad debt of vietnamese commercial banks in 2007-2013 Source: SBV (2014)

Meanwhile, competition from both local and foreign banks forces Vietnamese commercial banks to be more effective in the new environment. Banks with poor performance will be driven out by more effective ones and the most effective banks will have many competitive advantages.

The study questions how the relationship between bad debt and cost efficiency in Vietnamese commercial banks in the period 2007-2013 is. There are very few domestic researches examining this relationship though it is crucial. This paper tries to measure cost efficiency of the banks and test its relationship with bad debt in Vietnamese commercial banks during the years 2007-2013 when Vietnam was affected by the global 
financial crisis. The research results can help policy makers find suitable banking policies; bank managers understand performance of their banks, and the relationship between bad debt and cost efficiency in the surveyed period.

\section{Theoritical basis}

Bad debt comprises more than 90-day overdue debts classified in the Group 3 to the Group 5 (SBV, 2005).

The relationship between bad debt and cost efficiency has been widely discussed in many researches.

Firstly, many researches indicate that inefficient performance is considered as the cause of bank failure (Berger \& Humphrey, 1992; Wheelock \& Wilson, 1995). These inefficient banks often have a low cost efficiency and high ratios of bad debt due to banks' poor management in monitoring both their costs and borrowers. The reason for this problem, in addition, may be non-performing loans caused by exogenous factors, (e.g., regional economic recession) that make expenses associated with non-performing loans rise causing a low cost efficiency.

Secondly, existing empirical papers indicate that the relationship between cost efficiency and ratings of bank management quality is positive (Peristiani, 1996; DeYoung, 1998). DeYoung's study (1998), however, demonstrates that banks' management ratings are strongly related to their asset quality while relationship between asset quality and cost efficiency reflects a negative relationship between bad debt and cost efficiency.

Thirdly, with the aim of controlling expenses associated with bad debt, the most recent papers investigating bank efficiency measure bad debts in relation to cost (Hughes \& Mester, 1993). Moreover, according to Berger and DeYoung (1997), "a number of important policy and research issues - discovering the primary cause of problem loans and bank failures, determining the most important supervisory focus for promoting bank safety and soundness, and deciding how to estimate the cost efficiency of financial institutions - rest on identifying the underlying relationship between problem loans and measured cost efficiency."

Most empirical papers, such as works by Berger and Humphrey (1992), Wheelock and Wilson (1995) and Karim (2001), demonstrate that there exists an inverse relationship between bad debt and bank cost efficiency. Karim, Chan and Hassan (2010) 
uses stochastic cost frontier approach to measure cost efficiency and Tobit regression model to identify the relationship between bad debt and bank cost efficiency in Singapore and Malaysia. The results indicate that bad debt and bank cost efficiency exhibit an inverse relationship.

Tsai and Huang (1999) use the cost function to examine the relationship between management quality and cost efficiency in Taiwan's banking sector. The findings indicate that there is a direct relationship between cost efficiency and asset quality. By taking risk and quality factors into account when measuring the cost efficiency among Japanese commercial banks from 1993 to 1996, Altunbas, Liu, Molyneux and Seth (2000) demonstrate a direct relationship between level of bad debt and bank inefficiency.

Additionally, banks often experience a decrease in their efficiency after taking measures to manage risk factors. These findings are consistent with the researches on bank cost efficiency in the U.S. by Hughes and Mester (1993) and in the Italian banks by Girardone, Molyneux and Gardener (2004). Moreover, Fan and Shaffer (2004) analyze banks' efficiency in the U.S. considering bad debts and find that there exists an inverse relationship between bad debt and bank cost efficiency but this result is not statistically significant.

However, Koutsomanoli-Fillipaki and Mamatzakis (2009) and Berger and DeYoung (1997) demonstrate that bank efficiency is positively related to non-performing loans. Two hypotheses are usually used for explaining this result:

(i) In accordance with "skimping" hypothesis suggested by Berger and DeYoung (1997), reduced cost by "skimping on the resources devoted to underwriting and monitoring loans leads to the fact that banks' profits are maximized efficiently in the long term rather than the short term." However, this can make banks "bear the consequences of greater loan performance problems and the possible costs of dealing with these problems in the future." (Berger \& DeYoung, 1997)

(ii) Under "risk-averse management" hypothesis constructed by KoutsomanoliFillipaki and Mamatzakis (2009), banks tend to raise operating costs for underwriting and monitoring loans to reduce default risk and avoid credit problems and thus decrease bank efficiency. The direct relationship, in this case, between cost efficiency and nonperforming loans is explained by banks' fear of financial distress and asymmetric information. 


\section{Methodology}

The paper employs a non-parametric data envelopment analysis (DEA) to measure cost efficiency and make a comparison in indicator between Vietnamese commercial banks, then uses Tobit regression model to examine impacts of non-performing loans on bank cost efficiency and vice versa.

\subsection{Measuring the cost efficiency}

The best achieved performance is when no other bank can achieve a combination of smaller inputs to produce a preset output or vice versa. Using DEA approach to measure cost efficiency brings two obvious advantages: very few assumptions about production function and restriction on arbitrary assumptions about efficient frontier. Moreover, DEA method is widely used when dealing with complicated relationships between many output variables. Three efficiency measurement concepts are: (i) Technical efficiency is the ability to produce a preset quantity of output from the minimum quantity of inputs; (ii) Allocative efficiency is related to choosing resources of inputs for producing output at the lowest cost level; and (iii). Cost efficiency is a connection between two efficiencies above (Coelli et al., 2005).

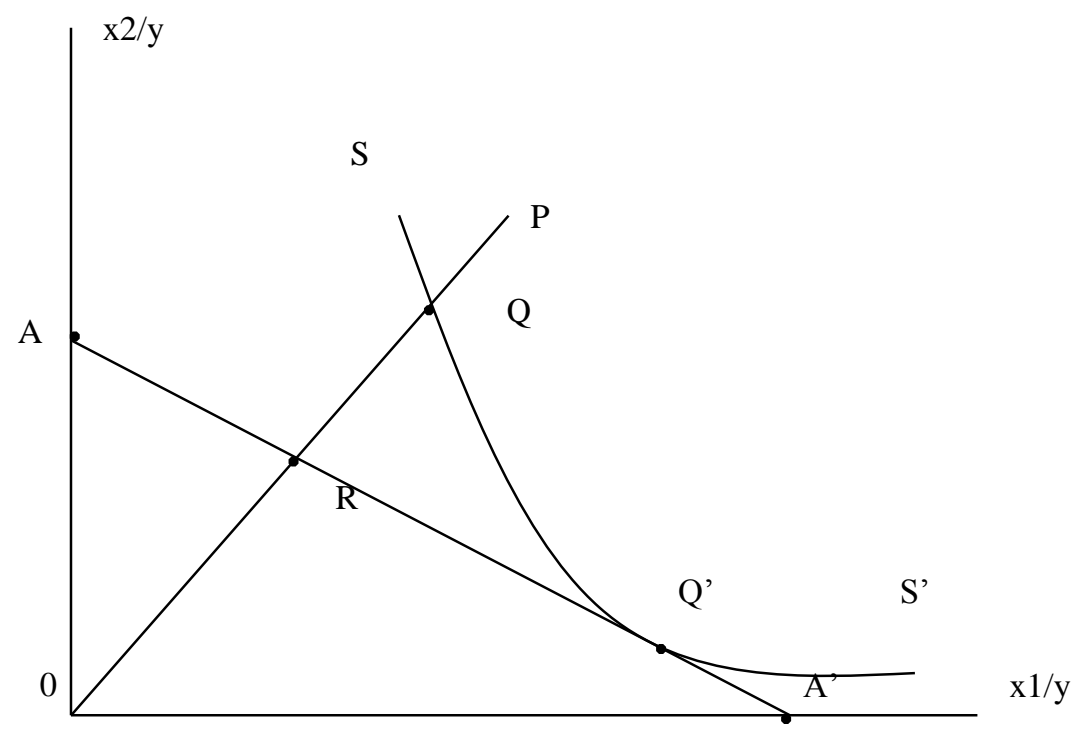

Fig. 2. Technical, allocative and cost efficiencies

Source: Coelli et al. (2005) 
Through Fig. 2, if a bank uses the quantity of inputs defined at $\mathrm{P}$, the following ratios are used to measure technical, allocative and cost efficiencies respectively:

$\mathrm{TE}=0 \mathrm{Q} / 0 \mathrm{P}$ (a bank achieves the maximum technical efficiency when TE equals 1 );

$\mathrm{AE}=0 \mathrm{R} / 0 \mathrm{Q}$; and

$\mathrm{CE}=\mathrm{AExTE}=0 \mathrm{Q} / 0 \mathrm{P} x 0 \mathrm{R} / 0 \mathrm{Q}=0 \mathrm{R} / 0 \mathrm{P}$.

Selection of output and input variables is based on the view that banks are intermediary financial institutions where deposits are an input factor used for producing income as an output. In this paper, two output variables (Y1) and (Y2) denote interest income and non-interest income respectively; input variables (X1), (X2) and (X3) denote labor cost, fixed asset and customer deposit respectively (Nguyen, 2012).

\subsection{Tobit model}

To determine the relationship between non-performing loans and bank cost efficiency, the author employs the Tobit model with the efficiency scores that are bounded from zero to one. The Tobit model, developed by Tobin (1958), is known as a censored regression model with expected errors at zero. The Tobit model can be defined as follows:

$$
\begin{aligned}
E F F_{i}^{*} & =\beta^{\prime} X+\varepsilon_{i}, \varepsilon_{i} \sim N\left(0, \sigma^{2}\right) \text { with } 0<E F F_{i}^{*}<1 \\
E F F_{i} & =0 \text { if } E F F_{i}^{*}=0 \\
E F F_{i} & =1 \text { Otherwise. }
\end{aligned}
$$

Where $E F F_{i}$ denotes cost efficiency, $E F F_{i}^{*}$ denotes cost efficiency scores measured by DEA approach; $\beta$ and $\mathrm{X}$ represent vectors of parameters to be estimated and explanatory variables; and $\varepsilon, \mathrm{v}$ represent normally distributed error terms (Karim et al., 2010).

Many studies demonstrate that the relationship between non-performing loans and cost efficiency is bi-directional instead of unidirectional. Low cost efficiency reflects poor operations and loan portfolio management practices. In addition, poor management in credit operations can cause high bad debt ratios, and thus lead to the effect of efficiency on non-performing loans (Berger \& DeYoung, 1997).

Since the quantity of bad debt database in Vietnamese sample commercial banks is not adequate over years, author employs the Tobit equation regression models (Equation 2 and 3) to estimate the relationship between non-performing loans and efficiency, based 
on models developed by Karim et al. (2010) and added several factors to make them appropriate to Vietnam's conditions:

$$
\begin{aligned}
& E F F_{i t}=\alpha_{0}+\delta_{1} N P L_{i t}+\alpha_{1} S T A T E_{i t}+\alpha_{2} A S S E T_{i t}+\alpha_{3} A G E_{i t}+\varepsilon \\
& N P L_{i t}=\beta_{0}+\delta_{2} E F F_{i t}+\beta_{1} S T A T E_{i t}+\beta_{2} A S S E T_{i t}+\beta_{3} A G E_{i t}+\mathrm{v}(3)
\end{aligned}
$$

The explanatory variables used to estimate are NPL, STATE, ASSET, and AGE, where $N P L_{i t}$ denotes the ratio of non-performing loans to total loans of bank $i$ at time $t$. Variables used to control the effect of different factors on bank cost efficiency at year $t$ include: a dummy variable STATE that takes a value of 1 if the bank is state-owned and 0 if it is private-owned; ASSET that is natural logarithm of total asset value, measuring the effect of bank size (Karim et al., 2010); AGE that is the age of bank to control or bank's experience (Berger \& DeYoung, 1997; Karim et al., 2010). Also according to Karim et al. (2010), "banks that were established earlier are expected to be more efficient." Based on the above argument, hence, author expects that cost efficiency (EFF) is not positively related to non-performing loans (NPL).

\section{Research sample}

The paper mainly uses data from the annual reports of 30 commercial banks in Vietnam including: An Binh Commercial Joint Stock Bank (ABB), Asia Commercial Bank (ACB), Bank for Investment and Development of Vietnam (BIDV), Commercial Joint Stock Bank for Industry and Trade of Vietnam (CTG), Eastern Asia Commercial Joint Stock Bank (EAB), OCEAN Commercial Joint Stock Bank (DDB), Vietnam Export - Import Commercial Joint Stock Bank (EIB), Hochiminh City Housing Development Commercial Joint Stock Bank (HDB), Military Commercial Joint Stock Bank (MB), Housing Commercial Joint Stock Bank of Mekong Delta (MHB), Maritime Commercial Joint Stock Bank (MSB), Southern Commercial Joint Stock Bank (PNB), SaiGon Commercial Joint Stock Bank for Industry and Trade (SGB), Saigon - Hanoi Commercial Joint Stock Bank (SHB), Saigon Thuong Tin Commercial Joint Stock Bank (STB), Vietnam Technological and Commercial Joint Stock Bank (TCB), Viet A Commercial Joint Stock Bank (VAB), Vietnam International Commercial Joint Stock Bank (VIB), Commercial Joint Stock Bank for Foreign Trade of Vietnam (VCB), Vietnam Prosperity Commercial Joint Stock Bank (VPB), Orient Commercial Joint Stock Bank (OCB), Southeast Asia Commercial Joint Stock Bank (SEAB), Vietnam Capital Commercial Joint Stock Bank (VEB), Nam A Commercial Joint Stock Bank 
(NAB), Nam Viet Commercial Joint Stock Bank (NAV), Petrolimex Group Commercial Joint Stock Bank (PGB), Kien Long Commercial Joint Stock Bank (KLB), LienViet Post Commercial Joint Stock Bank (LPB), Western Commercial Joint Stock Bank (WEB), and Dai A Commercial Joint Stock Bank (DAB).

Some banks in the sample lack comprehensive data such as LPB (established in 2008), Dai A Bank and Viet Capital Bank (lacking 2007 and 2013 bad debt data), or fail to publish 2013 data, such as Viet Capital Bank, MHB, and Western Bank (being PVCombank after its merger with PVFC).

The following table describes the variables in the paper. Unit is VND million. Table 1 reveals that the average value of bad debt in 30 commercial banks over the years $2007-$ 2013 is VND996,185 million, accounting for 2.18\% of total loans; the bank with the highest average value is BIDV accounting for VND9,160,992 million; and the bank with the lowest one is Viet Capital Bank, VND102,253 million. In the surveyed period, additionally, the paper indicates that the banks' profits come mainly from interest income (VND7,010,811 million) rather than non-interest income (VND848,659 million).

\section{Table 1}

Variables of the sample in 2007-2013

\begin{tabular}{|c|c|c|c|c|c|c|c|c|c|}
\hline & $\begin{array}{l}\text { Bad debt } \\
\text { (VND } \\
\text { million) }\end{array}$ & $\begin{array}{l}\text { Interest } \\
\text { income } \\
\text { (VND } \\
\text { million) }\end{array}$ & $\begin{array}{c}\text { Non-interest } \\
\text { income } \\
\text { (VND } \\
\text { million) }\end{array}$ & $\begin{array}{l}\text { Labor cost } \\
\text { (VND } \\
\text { million) }\end{array}$ & $\begin{array}{c}\text { Fixed asset } \\
\text { (VND } \\
\text { million) }\end{array}$ & $\begin{array}{l}\text { Customer } \\
\text { deposit } \\
\text { (VND } \\
\text { million) }\end{array}$ & $\begin{array}{c}\text { Cost of } \\
\text { labor } \\
\text { (VND million } \\
\text { /person) }\end{array}$ & $\begin{array}{c}\text { Cost of } \\
\text { capital } \\
(\%)\end{array}$ & $\begin{array}{c}\text { Cost of } \\
\text { deposit } \\
(\%)\end{array}$ \\
\hline Average & 996,185 & $7,010,811$ & 848,659 & 583,813 & 515,139 & $50,207,269$ & 116,92 & 4.46 & 0.12 \\
\hline $\begin{array}{l}\text { Standard } \\
\text { deviation }\end{array}$ & $1,440,864$ & $8,253,544$ & $1,247,064$ & 850,435 & 571,099 & $64,339,026$ & 41,56 & 2.97 & 0.04 \\
\hline $\begin{array}{l}\text { Minimum } \\
\text { value }\end{array}$ & 102,253 & 68,502 & 1,755 & 8,100 & 17,936 & 417,162 & 26,47 & 0.66 & 0.02 \\
\hline $\begin{array}{l}\text { Maximum } \\
\text { value }\end{array}$ & $6,805,648$ & $55,775,244$ & $8,418,656$ & $4,769,481$ & $3,464,589$ & $364,497,001$ & 273,22 & 18.34 & 0.29 \\
\hline
\end{tabular}

Source: Calculated from annual reports of banks in 2007-2013. 


\section{Research results}

\subsection{Bank cost efficiency}

Table 2 shows average value of cost efficiencies of the banks in the sample from 2007 to 2013 is $52.6 \%$, demonstrating that banks did not employ their input to the fullest. Thus, banks can reduce expenses to enhance their performance. The banks in the sample gaining the lowest average value of overall economic efficiency include CTG (30.5\%), MHB (32.9\%), DAB (37.6\%) and BIDV (39.9\%). Meanwhile, those in the sample achieving the highest average value of cost efficiency include DDB (78.0\%) and VAB (75.9\%). In the whole period of research, Vietnamese commercial banks achieve the lowest cost efficiency in 2010 and 2013 (Fig. 3).

In addition, technical efficiency value of all 30 banks in the sample is $76.8 \%$ where four state-owned commercial banks reach a lower value than joint-stock commercial banks: $70.4 \%$ compared to $77.8 \%$, which demonstrates that input resources as labor, capital and techniques are better employed by joint-stock banks than by state-owned ones.

\section{Table 2}

Estimation results of average efficiency of Vietnamese commercial banks in 2007-2013

\begin{tabular}{cccc}
\hline Bank & $\begin{array}{r}\text { Technical } \\
\text { efficiency }\end{array}$ & $\begin{array}{c}\text { Allocative } \\
\text { efficiency }\end{array}$ & Cost efficiency \\
\hline ABB & 0.575 & 0.715 & 0.411 \\
ACB & 0.668 & 0.750 & 0.502 \\
BIDV & 0.774 & 0.515 & 0.399 \\
CTG & 0.629 & 0.485 & 0.305 \\
EAB & 0.711 & 0.809 & 0.576 \\
DDB & 1.000 & 0.780 & 0.780 \\
EIB & 0.709 & 0.635 & 0.451 \\
HDB & 0.794 & 0.727 & 0.577 \\
MB & 0.711 & 0.729 & 0.518
\end{tabular}


Table 2 (continued)

\begin{tabular}{|c|c|c|c|}
\hline Bank & $\begin{array}{l}\text { Technical } \\
\text { efficiency }\end{array}$ & $\begin{array}{l}\text { Allocative } \\
\text { efficiency }\end{array}$ & Cost efficiency \\
\hline MHB & 0.702 & 0.469 & 0.329 \\
\hline MSB & 0.909 & 0.713 & 0.648 \\
\hline PNB & 0.839 & 0.854 & 0.717 \\
\hline SGB & 0.782 & 0.691 & 0.540 \\
\hline SHB & 0.793 & 0.679 & 0.539 \\
\hline STB & 0.639 & 0.643 & 0.411 \\
\hline TCB & 0.828 & 0.849 & 0.703 \\
\hline VAB & 0.860 & 0.882 & 0.759 \\
\hline VIB & 0.863 & 0.788 & 0.680 \\
\hline VCB & 0.667 & 0.645 & 0.430 \\
\hline VPB & 0.776 & 0.758 & 0.589 \\
\hline OCB & 0.733 & 0.625 & 0.458 \\
\hline SEAB & 0.878 & 0.749 & 0.658 \\
\hline VEB & 0.976 & 0.694 & 0.677 \\
\hline NAB & 0.866 & 0.618 & 0.535 \\
\hline NAV & 0.761 & 0.544 & 0.414 \\
\hline PGB & 0.741 & 0.616 & 0.457 \\
\hline KLB & 0.888 & 0.592 & 0.526 \\
\hline LPB & 0.719 & 0.608 & 0.437 \\
\hline WEB & 0.684 & 0.701 & 0.479 \\
\hline DAB & 0.623 & 0.603 & 0.376 \\
\hline Average & 0.768 & 0.685 & 0.526 \\
\hline
\end{tabular}

Source: Calculated from DEAP 2.1 


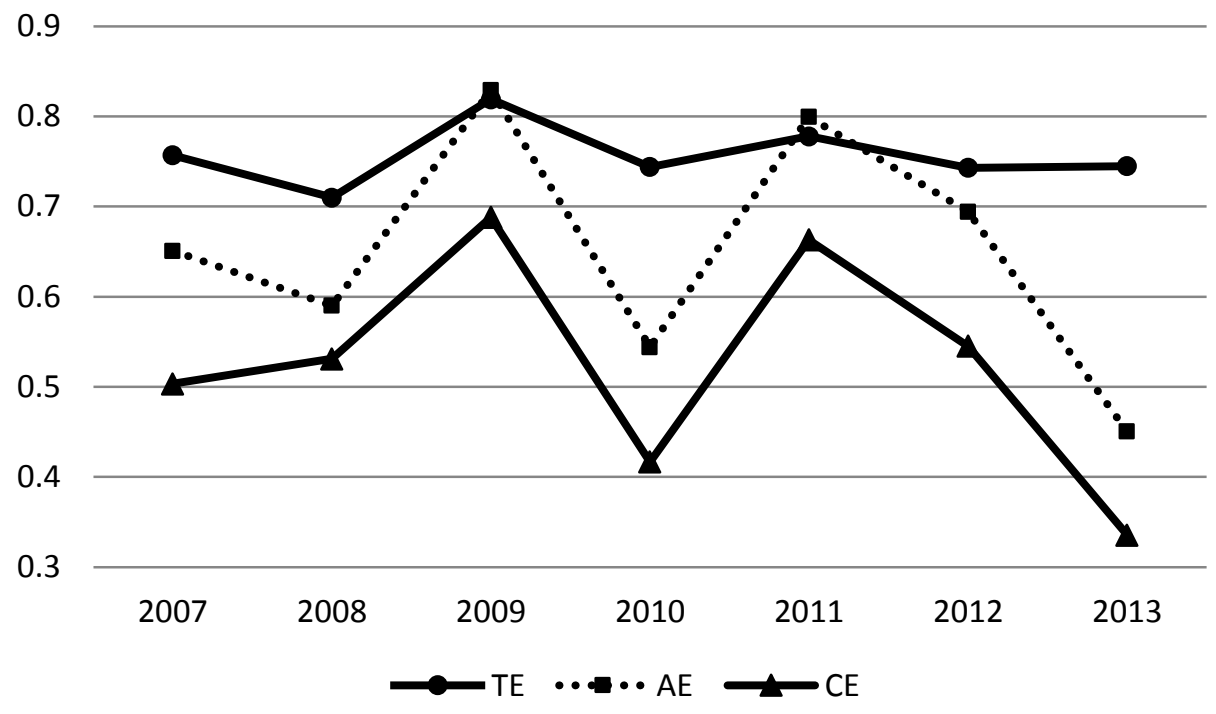

Fig. 3. Technical, allocative and cost efficiencies of Vietnamese commercial banks in 2007-2013 (Unit: \%)

Source: Calculated from DEAP 2.1

\subsection{Results of Tobit regression model}

The regression results of the Tobit model for relationship between non-performing loans and bank cost efficiency are presented in Table 4.

\section{Table 4}

Estimation results of Tobit model

\begin{tabular}{lccc}
\hline \multicolumn{3}{c}{ Dependent variable: EEF } \\
\hline C & Regression Coefficient & Standard error & t-value \\
NPL & 0.2522 & 0.4935 & $2.75^{*}$ \\
ASSET & 2.5645 & 1.0320 & $1.75^{*}$ \\
STATE & 0.0410 & 0.0270 & 1.48 \\
AGE & -0.2430 & 0.0810 & -0.50 \\
\hline
\end{tabular}


Table 4 (continued)

\begin{tabular}{lccc}
\hline \multicolumn{3}{c}{ Dependent variable: NPL } \\
\hline C & Regression Coefficient & Standard error & t-value \\
\hline EEF & 0.6524 & 0.1596 & $4.09^{* * *}$ \\
ASSET & 0.1226 & 0.0900 & $1.75^{* *}$ \\
STATE & -0.0035 & 0.0010 & -3.67 \\
AGE & 0.0036 & 0.0037 & 0.98 \\
\hline
\end{tabular}

Note: $(* * *),(* *)$ and $(*)$ denote statistical significance levels of $1 \%, 5 \%$ and $10 \%$ respectively.

Source: Tobit regression results with Stata 11.0

The results, from the Tobit regression model in Table 3, show that regression coefficient of non-performing loans NPL is positive when dependent variable EFL represents cost efficiency (with statistical significance level of 10\%). In addition, regression coefficient of cost efficiency is also positive when dependent variable is nonperforming loans (with statistical significance level of 5\%). According to the results, an increase in bank cost efficient can lead to a raise in non-performing loans, and vice versa.

In Fig. 4, 53.11\% and $66.31 \%$ increases in bank cost efficiency result in $2.16 \%$ and $2.20 \%$ increase in non-performing loans in 2008 and 2011 respectively. Contrarily, bank cost efficiency will fall when non-performing loans fall (in 2007, 2010 and 2013).

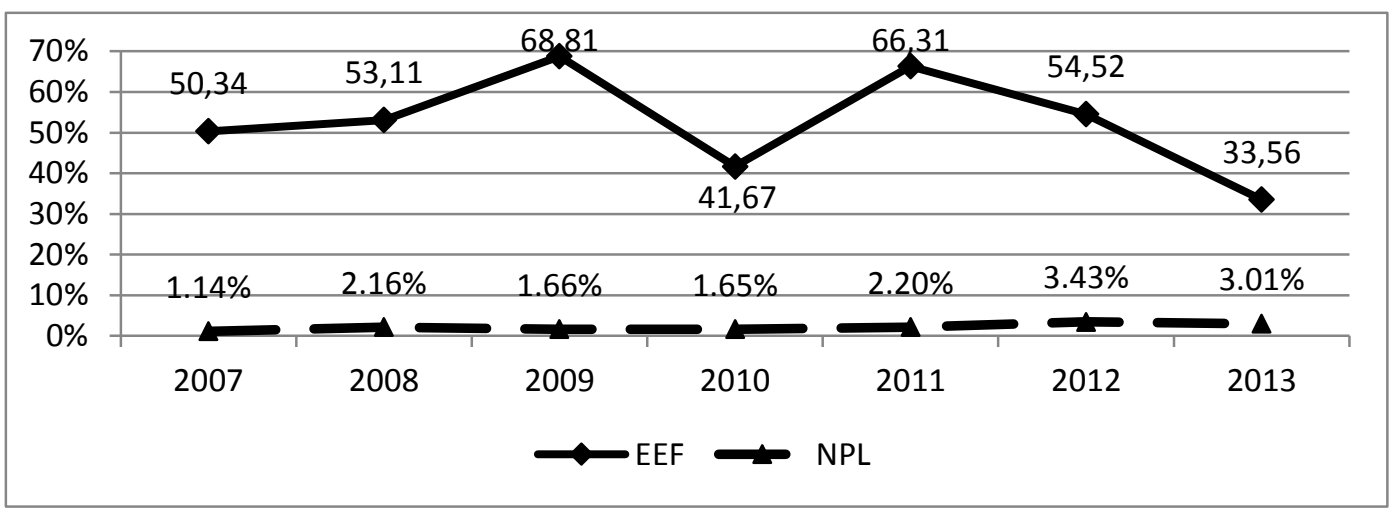

Fig. 4. Bad debt and cost efficiency in 30 Vietnamese commercial banks in 2007-2013 
Source: Calculated from DEAP 2.1 and financial statements of Vietnamese commercial banks in 2007- 2013

The risk-averse management hypothesis suggested by Koutsomanoli et al. (2009) could be used to explain the relationship. The banks tend to raise monitoring fees on loan quality and non-performing loans. A growing instability in the banks due to an increase in nonperforming loans warns about the beginning of the financially unstable period. Thus, the banks must allocate more resources for monitoring loans, leading to a decrease in bank efficiency. However, this also makes the ratio of non-performing loans lower.

The results is also in agreement with the "skimping" hypothesis suggested by Berger and DeYoung (1997) in which banks tend to reduce costs for managing and monitoring loans in an effort to maximize their profit, which improves cost efficiency in a short term because less resources are spent on bad debt management. The reduced costs cannot affect non-performing loans in the short run but in the long run the slack control over loans due to cuts in expenses may lead to an increase in non-performing loans. Therefore, the effort to raise cost efficiency can make banks bear the later consequences of bad debt increase.

\section{Conclusion}

Over 30 commercial banks in Vietnam are surveyed as the sample for study on the relationship between bad debts and cost efficient in the banks over the years 2007-2013. The results show the average cost efficiency in the banks is $52.6 \%$. The relationship between cost efficiency and bad debt is demonstrated by the Tobit regression model. However, the research results can be affected by shortcomings in disclosure of banks' information, and bad debt ratios published by Vietnamese commercial banks may be inaccurate and intransparent.

The paper also demonstrates that a decrease in bank cost efficiency is due to other policies in addition to non-performing loans. Policy makers, owners and banking administrators should initially realize that the main risks banks are facing are more likely to come from internal factors, mainly their bad management (Berger \& DeYoung, 1997). To ensure a strong banking system, hence, managerial skills should be improved.

\section{Recommendations}

It is necessary for Vietnamese commercial banks to publish sufficient, accurate and transparent financial information needed for estimations of the relationship between bad 
debts and bank cost efficiency. In order to achieve the goal, SBV should complete the legislation on information disclosure, especially about non-performing loans and types of debts, including appropriate penalties for non-compliance of Vietnamese commercial banks as a whole.

According to regulations of the Ministry of Finance, for example, both public organizations and joint-stock commercial banks must build their own website with an "Investors" item in which information about financial situation is periodically disclosed to shareholders. Nevertheless, now only a few out of 84 listed commercial banks carry out such periodical disclosure as required by the regulations. Thus, it is very difficult for investors to grasp financial information about banks whose stocks are not yet listed, not to mention the fact that information may not be published timely and fully.

The research results show that the relationship between bad debt and cost efficiency is in the same direction; therefore, when both bad debt and cost efficiency increase, banks should monitor loans more tightly because such increase in bank efficiency may last only a short period. Additionally, SBV should require commercial banks to make adequate provisions and enhance the resources for monitoring loans. Regarding the Basel II regulatory framework, Rossi, Schwaiger and Winkler (2009) state that the process of supervising and monitoring loans is an important step for a risk-sensitive financial system. The more efficient banks are those that have better conditions for risk management.

The results also demonstrate low cost efficiency in Vietnamese commercial banks (52.6\%), so author suggests the following recommendations for Vietnamese banks to enhance their cost efficiency:

Firstly, the commercial banks in Vietnam should strictly control interest costs, employee costs and capital costs, and build long-run strategies to reduce such costs and improve labor productivity. Additionally, the banks need to control more tightly capital and interest costs, thereby effectively enhancing input resource efficiency.

Secondly, the banks should focus on developing reasonable policies on cost management, especially costs for management and using capital.

Thirdly, it is essential to enhance the risk management efficiency, especially liquidity risk management in order to reduce costs due to liquidity shocks. Liquidity risks and interest rate racing among commercial banks in Vietnam tend to increase their costs and decrease their efficiency of input resources. To improve the liquidity risk management efficiency, the banks should complete the management procedure by applying modern 
measurements associated with different scenarios of market fluctuations with efficient assistance of banking technology.

Lastly, Vietnamese commercial banks should control bad debts and their asset quality, thereby reducing capital costs. The banks could apply various methods to reduce nonperforming loans, such as: (i) selling mortgaged assets; (ii) recovering positively loans; (iii) rescheduling and reassessing loans; (iv) selling loans to debt trading companies; and (v) using risk provision. However, the long-term strategies require Vietnamese commercial banks to take the precautions against non-performing loans such as completing credit policies in accordance with international standards, which is considered as a prerequisite for uniform and close compliance of credit policies. It is also crucial to improve management mechanism, control risks and adopt experience from foreign banks, thereby implementing credit analysis based on cash flow and monitoring borrowers' solvency.

Moreover, SBV also need to establish a strong regulatory framework to deal with bankruptcy and seizure. In addition to decreasing bad debt, the banks should improve asset quality in order to reduce costs and increase resource efficiency, such as making reasonable policies on investment, enhancing the roles of inspection and internal control, thereby ensuring that the information of the whole system is transparent and smooth.

The shortcoming is that this paper could not classify the banks according to their capital size or included different level of banks' growth on the market or varied types of bad debts. In addition, the study did not access foreign banks operating in Vietnam. Thus, the aforementioned relationship will be clearly examined in the future researches by classifying types of bad debts as well as bank size and comparing efficiency of the local and foreign banks

\section{References}

Altunbas, Y., Liu, M. H., Molyneux, P., \& Seth, R. (2000). Efficiency and risk in Japanese banking. Journal of Banking and Finance, 24(10), 1605-1628.

Berger, A. N., \& DeYoung, R. (1997). Problem loans and cost efficiency in commercial banks. Journal of Banking and Finance, 21, 849-870.

Berger, A. N., \& Humphrey, D. B. (1992). Measurement and efficiency issues in commercial banking. In Z. Griliches (Ed.), Output measurement in the services sectors (pp. 245-279). Chicago: University of Chicago Press. 
Coelli, J.T., Rao, D.S.P., O’Donnell, C.J., \& Battese, G.E. (2005). An introduction to efficiency and productivity analysis, New York: Spinger Science + Business Media, Inc.

DeYoung, R. (1998). Management quality and X-efficiency in national banks. Journal of Financial Services Research, 13(1), 5-22.

Fan, L., \& Shaffer, S. (2004). Efficiency versus risk in large domestic US banks. Managerial Finance, 30(9), 1-19.

Girardone, C., Molyneux, P., \& Gardener, E. P. (2004). Analysing the determinants of bank efficiency: The case of Italian banks. Applied Economics, 36(3), 215-227.

Hughes, J. P., \& Mester, L. J. (1993). A quality and risk-adjusted cost function for banks: Evidence on the 'Too-big-to-fail' doctrine. Journal of Productivity Analysis, 4, 293-315.

Karim, M. Z. A. (2001). Comparative bank efficiency across select ASEAN countries. ASEAN Economic Bulletin, 18(3), 289-304.

Karim, M. Z. A., Chan, S.G., \& Hassan, S. (2010). Bank efficiency and non-performing loans: Evidence from Malaysia and Singapore. Prague Economic Papers, 2, 118-132.

Koutsomanoli-Fillipaki, A., \& Mamatzakis, E. (2009). Performance and Merton-type default risk of listed banks in the EU: A panel VAR approach. Journal of Banking and Finance, 33(11), 20502061.

Nguyen, T.H.V. (2012). Measuring the technical effectiveness and Malmquist index of the Vietnam commercial banks (in Vietnamese). Banking Technology Review, 74, 16-23.

Peristiani, S. (1996). Evaluating the post merger X-efficiency and scale efficiency of U.S. banks (Working paper) New York: Federal Reserve Bank of New York.

Rossi, S. P. S., Schwaiger, M. S., \& Winkler, G. (2009). How loan portfolio diversification affects risk, efficiency and capitalization: A managerial behavior model for Austrian banks. Journal of Banking and Finance, 33(12), 2218-2226.

State Bank of Vietnam. (2014). Monetary-banking statistics (in Vietnamese). Retrieved March 31, 2014, from http://sbv.gov.vn/portal/faces/vi/vim/vipages_trangchu/tkttnh/hdhttctd/tlnx?_adf.ctrlstate $=14 f 3 b h 0 o 7 d \_4 \& \_a f r L o o p=6525861870900800$.

Staub, R. B., da Silva e Souza, G., \& Tabak, B. M. (2010). Evolution of bank efficiency in Brazil: A DEA approach. European Journal of Operational Research, 202(1), 204-213.

Tobin, J. (1958). Estimation of relationships for limited dependent variables. Econometrica, 26(1), 24-36.

Tsai, D. H., \& Huang, F. W. (1999). Management quality and bank efficiency: Empirical evidence for Taiwanese banks. Management Review, 18(3), 35-55.

Wheelock, D. C., \& Wilson, P. W. (1995). Explaining bank failures: Deposit insurance, regulation, and efficiency. Review of Economics and Statistics, 77, 689-700. 